\title{
Correction to: LEDGINs inhibit late stage HIV-1 replication by modulating integrase multimerization in the virions
}

Belete Ayele Desimmie ${ }^{1 \dagger}$, Rik Schrijvers ${ }^{1 \dagger}$, Jonas Demeulemeester ${ }^{1 \dagger}$, Doortje Borrenberghs ${ }^{2 \dagger}$, Caroline Weydert ${ }^{1}$, Wannes Thys ${ }^{1}$, Sofie Vets ${ }^{1}$, Barbara Van Remoortel ${ }^{1}$, Johan Hofkens ${ }^{2}$, Jan De Rijck ${ }^{1}$, Jelle Hendrix ${ }^{2}$, Norbert Bannert ${ }^{3}$, Rik Gijsbers ${ }^{1}$, Frauke Christ $^{1}$ and Zeger Debyser ${ }^{1 *}$

\section{Correction to: Retrovirology (2013) 10:57} https://doi.org/10.1186/1742-4690-10-57

Following publication of their article [1], the authors realized that an error occurred in Figure $3 f$ during mounting of the Figure for the p55 band ( 2 different blots were used, which was not indicated in the figure legend). Therefore, the authors would like to replace Fig. 3f with a new one based on one single experiment and blot. This new Figure does not affect any results or conclusions.

${ }^{*}$ Correspondence: Zeger.debyser@med.kuleuven.be

${ }^{\dagger}$ Belete Ayele Desimmie, Rik Schrijvers, Jonas Demeulemeester and

Doortje Borrenberghs contributed equally to this work

${ }^{1}$ Department of Pharmaceutical and Pharmacological Sciences,

Laboratory for Molecular Virology and Gene Therapy, KU Leuven,

Kapucijnenvoer 33, 3000 Louvain, Flanders, Belgium

Full list of author information is available at the end of the article

(c) The Author(s) 2020. This article is licensed under a Creative Commons Attribution 4.0 International License, which permits use, sharing, adaptation, distribution and reproduction in any medium or format, as long as you give appropriate credit to the original author(s) and the source, provide a link to the Creative Commons licence, and indicate if changes were made. The images or other third party material in this article are included in the article's Creative Commons licence, unless indicated otherwise in a credit line to the material. If material is not included in the article's Creative Commons licence and your intended use is not permitted by statutory regulation or exceeds the permitted use, you will need to obtain permission directly from the copyright holder. To view a copy of this licence, visit http://creativecommons.org/licenses/by/4.0/. The Creative Commons Public Domain Dedication waiver (http://creativecommons.org/publicdomain/zero/1.0/) applies to the data made available in this article, unless otherwise stated in a credit line to the data. 


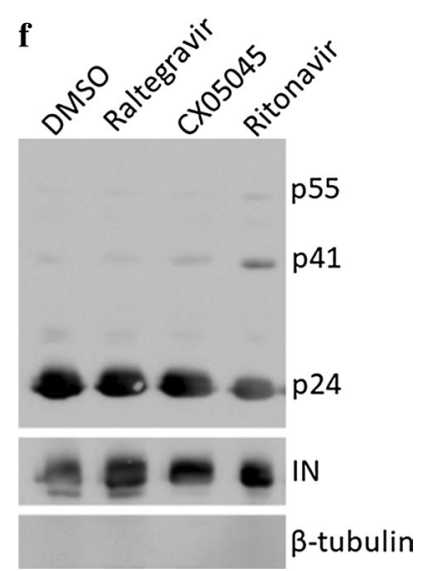

Fig. 3 f Western blot analysis of viral proteins in $\mathrm{HUT7}_{\text {IIIB }}$ producer cells or the corresponding cell-free viruses produced in the presence of the indicated compounds. $\beta$-tubulin was used as loading control. Scale bars represent $500 \mathrm{~nm}$

\section{Author details}

${ }^{1}$ Department of Pharmaceutical and Pharmacological Sciences, Laboratory for Molecular Virology and Gene Therapy, KU Leuven, Kapucijnenvoer 33, 3000 Louvain, Flanders, Belgium. ${ }^{2}$ Laboratory for Photochemistry and Spectroscopy, KU Leuven, Celestijnenlaan 200F, 3001 Heverlee, Flanders, Belgium. ${ }^{3}$ Centre for HIV and Retrovirology, Robert Koch Institute, Nordufer 20, 13353 Berlin, Germany.

Published online: 29 July 2020

\section{Reference}

1. Desimmie BA, Schrijvers R, Demeulemeester J, Borrenberghs D, Weydert C, Thys W, Vets S, Van Remoortel B, Hofkens J, De Rijck J, Hendrix J, Bannert N, Gijsbers R, Christ F, Debyser Z. LEDGINs inhibit late stage HIV-1 replication by modulating integrase multimerization in the virions. Retrovirology. 2013;10:57. https://doi.org/10.1186/1742-4690-10-57.

\section{Publisher's Note}

Springer Nature remains neutral with regard to jurisdictional claims in published maps and institutional affiliations. 